shore. The theory suggests a definit 9 two to one relationship between the periods of the sea-waves and microseisms, which has been confirmed by observations. Further, by submitting simultaneous records of waves and microseisms to frequency analysis, it has been thought safe to conclude that a depression moving rapidly over deep water north of the Azores caused microseisms at Kew. Microseisms on Kew seismograms can be detected some thirty hours before the swell from a distant storm reaches the coast.

ERnest Tillotson

$$
\text { ph }
$$

\section{MAGNETIC AMPLIFIERS}

$\mathrm{T}$ HE thermionic valve amplifier is so universal in its applicat nn al even the existence of other means of amplfying ends to be overlooked. Two papers read receftly before the Institution of Electrical Engineers record developments in magnetic amblip rs, and indicate the field of application within which such amplifiers possess advantages. Thespe porsers, "Magnetic Amplifiers", by A. G. Mibles, as "A Theoretical and Experimental Study of the Series-Connected Magnetic Amplifier", by H. M. Gale and P. D. Atkinson, were presented on December 2, 1948.

Essentially the principle of the magnetic amplifier is that of controlling the current in an A.c. circuit by varying, by means of an auxiliary D.C. circuit, the impedance of an iron-cored reactor in series with the load. The D.c. circuit thus effects its control by producing magnetic saturation of the reactor core. This principle has been known and has been applied for many years, indeed since the period of the First World War; but it was not until high-permeability nickel-iron alloys and metal rectifiers became available that rapid development of the magnetic amplifier for a wide range of applications took place.

The basic circuit arrangements of magnetic amplifiers have now assumed fairly well established forms, and the present papers give a systematic theoretical treatment and design procedure for the standard circuits. As a rule the magnetic amplifier operates as a D.C. amplifier in the sense that the input or controlling current is a small direct current, and the output is again a direct current produced by the rectification of the alternating current passed by two reactors, the reactance of which is controlled by the input. A simple, single-stage magnetic amplifier employing high-permeability cores might give a power-gain of the order of 10 to 20. This gain may be very greatly increased, however, by the use of positive feed-back. Feed-back is applied by circulating the direct output current through an additional winding on the cores. If the magnetic effect of this feed-back winding is in such a direction as to reinforce that of the input current, there is partial self-excitation which increases the ratio of output current to input current. The effects of feed-back are closely analogous to those obtained with thermionic amplifiers, and excessive positive feed-back will give rise to instability. Positive feed-back is commonly utilized to obtain power gains per stage of the order of 2,000 . Without feed-back a magnetic amplifier does not discriminate between positive and negative input signals; but with the application of feed-back, reversal of the polarizing flux changes the feed-back from positive to negative, and discrimination results. Magnetic amplifiers commonly operate with input powers of the order of a microwatt, and it is stated in one of the papers that $10^{-8}$ watt may be regarded as the lower usable limit of input power.

Perhaps the most significant difference between the behaviour of the magnetic amplifier and that of the thermionic amplifier lies in the time delay of the response of the magnetic amplifier to a sudden change of input. The build-up of the steady state following a sudden alteration of input is approximately exponential, and the response-time of magnetic amplifiers is usually expressed as the time-constant of an approximately equivalent exponential rise. This time delay, which is practically inversely proportional to the frequency of the A.c. supply and increases in proportion to the stage amplification, is one of the important limiting factors in the application of magnetic amplifiers. In order to obtain a high ratio of amplification to time-constant it is desirable to connect a number of stages in cascade, since the overall amplification is the product of the amplifications of the individual stages, whereas the total time-constant is, very roughly, the sum of the time-constants of the stages.

It is interesting to note that in the two papers the theoretical analysis proceeds along quite different lines, and different approximate-design techniques are developed. It is pointed out that a magnetic amplifier to control a given power output is ordinarily considerably larger than the corresponding power transformer, and supply frequencies in the range 400-1,600 c. s. are commonly employed in order to reduce the size of the equipment. The equivalent exponential delay of an amplifier is stated to correspond to a time-constant of the order of 2-100 cycles of the supply frequency. JAMES GREIG

\section{$I_{\mathrm{d}}^{\mathrm{N}}$}

\section{RECRUITMENT AND TRAINING FOR THE IRON AND STEEL} INDUSTRY order that continuous and rapid technical developmans in the iron and steel industry shall not outruiline capabilities of the men who will be required.to operate the processes involved, the Brish Iron and Steel Federation has recently pre atred recruitment and training schemes to benefit the industry as a whole. Based on the experience gained by various firms who have already developed training programmes of a far-reaching character, the Recruitment and Training Committee of the Federation has introduced a sample training scheme which has been circulated to all member firms. In order that the scheme should be fully discussed and improved, a Conference was held at Ashorne Hill, Leamington, on January 14-16, 1949, under the chairmanship of Mr. Gerald Steel, joint managing director of the United Steel Companies. The Conference was attended by representatives of member firms from all parts of Britain, and included production managers as well as personnel officers of various grades.

Pointing out that the number of youths in industry between the ages of 14-18 years had fallen from $3 \frac{1}{4}$ millions in 1938 to $2 \frac{1}{2}$ millions in 1947 , Mr. A. Goodram, of Samuel Fox and Co., Ltd., discussed the training of the junior operative both from the economic and social points of view. In his own Company the 
scheme began with a period of three weeks pre-entry training in which the change-over from school to work was cushioned and gave the boy and girl some idea of the shape and importance of the firm and of its general organisation. The boy's first job as a messenger lasted eight months, and during this time he obtained more information about individuals, departments and processes. The next phase of training was given in the workshops, when suitable boys were selected as craft apprentices. Junior operatives were then placed in production departments until they were called up for National Service; but during this time they would be given experience in at least three departments as well as opportunities for attending educational institutions on one day a week.

The director of training at Stewarts and Lloyds, Ltd., Mr. Graham Satow, then outlined a scheme for training craft apprentices and suggested re-introduction of the formal method of 'agreements'. Training should include both technical and general aspects, and should be the joint responsibility of the firm and the local education authority. For the more able apprentice, education up to the ordinary and higher national certificate standards should be provided, while for the craftsman who was good with his hands a less academic examination should be instituted. Practical training should be done by the firm, and should include experience in the use of hand and machine tools as well as the actual jobs associated with the boy's future work. Selected craft apprentices should be given both the opportunity of moving up to the technical apprentice-level and of sitting for State technological scholarships.

In opening a discussion on the training of technical apprentices, Mr. Cleghorn Thomson, chief education officer of Richard Thomas and Baldwins, Ltd., indicated that these would generally be recruited from grammar school boys of matriculation standard. His suggestions for training this type of apprentice presupposed that ultimately the heads and chief assistants in the chemical, metallurgical and fuel departments of the larger works would all be honours degree men, or associates of the appropriate professional bodies, that ordinary degree men would be in charge of the main sections under them, and that foremen testers and senior chemists and testers should have at least higher national and national certificates, respectively. Training of technical apprentices in the works should provide progressive movement linked up with their theoretical studies and success in examinations. The period of training would last about five years and would include time spent in other firms. During the ensuing discussion the doubt was expressed whether it would be practicable to insist on matriculation as the prerequisite for this type of entrant to industry, while the need for universities to provide more facilities for parttime studies was strongly advocated.

The training of clerical workers was introduced by Mr. D. R. O. Thomas, chief education officer to the United Steel Companies, who emphasized that this was an aspect of industrial training which had not been given the attention that its importance required and merited. The national certificate in commerce had not yet gained wide acceptance mainly because it had not been sponsored by any single authoritative body. This situation may be altered after the CarrSaunders Committee, which is deliberating at present, has reported. The training should include preliminary instruction in the history and organisation of the firm, practical training in various departments and, concurrently with the practical training, theoretical training at a commercial college which should not be over-weighted on the vocational side. In summing up this particular session, the chairman insisted that the training provided "must wipe out that unfortunate figure, the routine clerk keeping up appearances on a miserable pittance".

Probably the most difficult subject at the Conference, training in the small firm, was tackled by Mr. A. Roebuck, technical director of Hadfield's, Ltd. Training in the small firm is as necessary as in the big firm, and Mr. Roebuck believed that this would be achieved if small firms would co-operate in groups on a trade or geographical basis. This is already happening in some parts of Great Britain, and in order to extend training facilities throughout the country it is proposed to set up local committees in various steel-making areas to help in the organisation of suitable training schemes. In this way large and small firms would be able to help each other, the small firm often making a contribution to training which was impossible in the bigger firm.

In surveying the work of the Conference, Mr. Geoffrey Summers, director of John Summers and Sons, Ltd., emphasized that all technical training needed to be reinforced with social and humanistic education in which young industrial workers should be taught how to make their leisure a period of profitable active enjoyment.

The Conference closed on an evangelical note with the following remarks by Mr. G. Steel. "We must proselytize. We must make everyone training. conscious. For the welfare of our own industry and the country as a whole, it is essential that we succeed. Only thus can we ensure that the best possible use is made of our strictly limited resources."

These words, and the calling of the Conference, indicate the way in which the iron and steel industry in Britain is adjusting itself to become more and more efficient in a world that daily grows more competitive.

\section{T. H. HawKINS}

\section{POTATO VIRUS $X$}

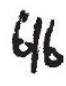

$T$ HE drastic roguing which is performed on crops of potatoes for seed has resulted in a reduction of the amount of the obvious viruses leaf-roll and rugose-mosaic. Notato virus $X$, however, causes a slight mottl or the foliage which is noticeable only under oftain ( onditions of weather, and may often be anissed by the roguers. F. C. Bawden, B. Kassanis and $\mathrm{M}_{\mathrm{M}}$. Roberts conclude, in a recent paper ( $A n n$. App. Biol., 25, No. 2, 250-265 ; June 1948), that the control of virus $X$ must involve methods additional to those of field inspection. Presence of the virus in a stock of potatoes can be tested by inoculation to indicator plants and by serological methods. Spread of the virus is slow under natural conditions, and the authors conclude that the maintenance of stocks from which virus $X$ has been eliminated by testing is feasible under commercial conditions. The virus reduces yield by 5-24 per cent; but it is refreshing to find the idea of clonal selection also considered along with questions of yield and loss due to virus.

Potato virus $X$ is shown by F. M. Roberts ( $A n n$. App. Biol., 35, No. 2, 266-278; June 1948) to be transmitted by contact of leaves or roots. About ten per cent of healthy plants in contact with diseased 